\title{
Penerapan Teknologi Filtrasi dan Tower Penampungan Low Cost- Low Maintenance dalam Penyediaan Air Bersih Bagi Masyarakat Desa Bango Kepulauan Mantehage
}

\author{
Emma Mauren Moko ${ }^{1}$, Dino Rahardiyan ${ }^{2 *}$, Ferry Wantouw $^{3}$ \\ ${ }^{1}$ Program Studi Biologi, Fakultas Matematika dan Ilmu Pengetahuan Alam, Universitas Negeri Manado, Tondano \\ 95619 \\ ${ }^{2}$ Program Studi Agribisnis, Fakultas Pertanian, Universitas Katolik De La Salle Manado, Manado 95000 \\ ${ }^{3}$ Program Studi Teknik Sipil, Fakultas Teknik, Universitas Katolik De La Salle Manado, Manado 95000 \\ *Penulis Korespondensi, Dino Rahardiyan, Prodi Agribisnis, Fakultas Pertanian, Universitas Katolik De La Salle \\ Manado 95000. Email: drahardiyan@unikadelasalle.ac.id
}

\begin{abstract}
Abstrak
Kepulauan Mantehage merupakan gugusan kepulauan dalam wilayah Taman Laut Nasional Bunaken dengan luas sekitar 89.065 hektar bersama empat pulau lainnya yaitu Pulau Nain, Manado Tua, Siladen dan Bunaken. Kebutuhan air bersih merupakan permasalahan utama bagi masyarakat Desa Bango di gugusan Kepulauan Mantehage dimana sumber air besih bagi sekitar 120 kk hanya bersumber dari sumur yang terdapat di tengah desa. Sumur ini merupakan tempat bagi masyarakat untuk kegiatan mandi dan mencuci dan tidak dilengkapi dengan fasilitas kamar mandi. Program kegiatan pengabdian masyarakat bertujuan untuk melakukan revitalisasi sumber air bersih (sumur) masyarakat. Tower penampungan air kapasitas $5500 \mathrm{~L}$ menggunakan baja ringan merupakan konstruksi teknologi tepat guna dirancang bagi masyarakat kepulauan yang memang berada dalam lingkungan salinitas tinggi dan dilengkapi sistem filtrasi sederhana tiga tingkat (3 Stage) menggunakan bahan alami pasir, kerikil dan ijuk untuk memudahkan bagi masyarakat dalam merevitalisasi filter dengan bahan-bahan dan material yang tersedia di lingkungan sekitar. Hasil evaluasi kegiatan bagi masyarakat adalah terciptanya revitalisasi sumber air bersih bagi masyarakat, terjadinya transfer teknologi serta dampak sosial bagi masyarakat yaitu perubahan pola kegiatan mandi dan mencuci sebelum dilakukan di sumur desa setelah pelaksaan pengabdian kegiatan tersebut beralih ke rumah masing-masing.
\end{abstract}

Kata Kunci: Teknologi Filtrasi, Low Cost, Low Maintenance, Water Tower, Filtrasi, Pulau Mantehage.

\begin{abstract}
The island of Mantehage is one of the island clusters within the Bunaken Marine Conservation (Taman Laut Bunaken). A cluster reaching out to 89.065 hectares and consisting of the island of Mantehage and four other islands; Nain, Manado Tua, Siladen and the infamous island of Bunaken. Clean water has been a major issues amongst these island dweller in the far Northern regions of North Sulawesi, thus is one of the priority agenda that needs attention. Clean water availability issue has also been a major issue to the villagers of Bango Village on Mantehage. 120 households of the Bango Village only relies on a well at the center of the village. A well that is currently utilized for all activities of washing and cleaning of all villagers, in which this facility is not accomodated with public bath and wash rooms. In which this program was aimed to revitalize the village water supplies and facilities. This program prepared a unique water tower with a capacity of 5500 liters and designed to compensate the uniques environmental challeges of island dwellers in terms of humidity and high salinity exposure. Recycled light steel guage material was used as the main tower frame for low cost and low maintenance reasons within a coastal environment, besided the fact that the material is recycled and thus considered a green material. The whole system is then equipped with 3 stage filtration system that is easiily maintained with filtration materials that are simply found in the surroundings of the village. For the people of Mantehage, this program resulted in a revitalization of the a source of cleanwater for the village community as a ramification of technology transfer. Further social impacts of these activities also altered the communal sanitary habbits of the community by changing their daily sanitary activities which previously was done at the community well and now to their own homes.
\end{abstract}

Keywords: Filtration Technology, Low Cost, Low Maintenance, Water Tower, Clean Water, Mantehage Island 


\section{PENDAHULUAN}

\section{Analisis Situasi}

Kegiatan Program Pengembangan Desa Mitra (PPDM) dilaksanakan di Kepulauan Mantehage, khususnya di Desa Bango Mantehage, Kecamatan Wori, Kabupaten Minahasa Utara, Propinsi Sulawesi Utara. Kepulauan Mantehage merupakan gugusan kepulauan yang masuk dalam wilayah Taman Laut Nasional Bunaken yang didirikan berdasarkan Surat Keputusan Menteri Kehutanan Nomor: 730/Kpts-11/1991 tanggal 15 Oktober 1991 dengan luas sekitar 89.065 hektar bersama empat pulau lainnya yaitu Pulau Nain, Pulau Manado Tua, Pulau Siladen dan Pulau Bunaken dengan jumlah penduduk 26.387 jiwa (Anonymous, 2017). Secara geografis Pulau Mantehage terletak disebelah utara dari ujung Pulau Sulawesi pada posisi 1240 45' 20" BT $1^{\circ} 42^{\prime}$ 56" LU, dengan luas Pulau Mantehage 18,56 km2 terdiri dari dua pulau utama yang dikelilingi oleh bakau yang luas dimana luas bakau tersebut hampir sama dengan luas daratan pulau (Anonymous, 2012).

Secara geografis, Taman Laut Nasional Bunaken terletak di wilayah perairan 'segi tiga emas', merupakan jalur perairan laut menghubungkan wilayah laut Filipina, Papua dan Indonesia, sehingga merupakan wilayah dengan biodiversitas atau keanekaragaman hayati yang tinggi, lebih dari sekitar 3000 spesies ikan, 7 dari 8 spesies kerang raksasa terdapat di wilayah Bunaken, keragaman biota laut sangat tinggi, keanekaragaman terumbu karang yang lebarnya bisa mencapai $2.5 \mathrm{~km}$ dan tebing karang vertikal yang curam hingga 25-50 meter, tebing bawah air memiliki banyak ceruk, celah dan rekahan yang dijadikan sebagai tempat persembunyian berbagai jenis vertebrata dan invertebrata laut. Kebutuhan air bersih merupakan permasalahan utama bagi masyarakat di hampir semua gugusan kepulauan Sulawesi Utara dan menjadi salah satu agenda prioritas yang harus diselesaikan. Permasalahan ini juga menjadi bagian dari kehidupan masyarakat Desa Bango yang berada di gugusan Kepulauan Mantehage dimana sumber air bersih bagi sekitar $120 \mathrm{kk}$ hanya bersumber dari parigi atau sumur yang terdapat di tengah desa, air dari sumber sumur tersebut bersifat sedikit payau (brackish water).
Sumur ini merupakan tempat bagi masyarakat untuk melaksanakan semua aktifitas baik untuk mandi dan mencuci, dimana Fasilitas tersebut tidak dilengkapi dengan fasilitas apapun untuk memudahkan warga mengambil air, sumur hanya dilengkapi dengan timba sederhana untuk mempermudah masyarakat mengambil air selain itu sumur tersebut tidak dilengkapi dengan fasilitas kamar mandi, dimana semua aktifitas MCK dilakukan oleh warga di sekitar sumur tersebut, sedangkan sumber air minum berasal dari air reverse osmosis (RO) yang terletak di dekat sumur tersebut walaupun fasilitas tersebut tidak dilakukan maintenance berupa pembilasan untuk mencegah kontaminasi. Teknologi yang digunakan dalam sistem tersebut menyebabkan masyarakat kurang memahami dalam pelaksanaan maintenance, proses maintenance hanya bisa dilakukan okeh distributor. Pada pagi dan sore hari masyarakat Desa Bango membawa galon-galon di sekitaran sumur untuk mengisi air minum dan air untuk mengisi kamar mandi dan toilet masyarakat. Keadaan tersebut dapat dilihat pada gambar berikut ini

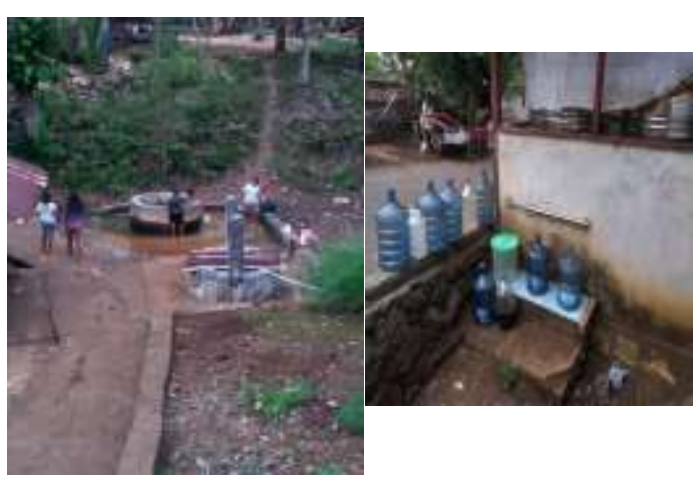

Gambar 1. Situasi Sumber Air (Sumur) Desa Bango

\section{Tujuan dan Manfaat Kegiatan}

Sesuai dengan rencana kegiatan tujuan dalam kegiatan pengabdian pada masyarakat ini adalah melakukan revitalisasi sumber air bersih bagi masyarakat Desa Bango, Kepulauan Mantehage. Kecamatan Wori, Kabupaten Minahasa Utara. 


\section{METODE PELAKSANAAN}

Solusi atas permasalahan yang dihadapi oleh masyarakat mitra di Desa Bango Kepulauan Mantehage dituangkan dalam beberapa metode pelaksanaan paket alih teknologi tepat guna melalui pendekatan edukasi dan partisipatif bagi masyarakat dewasa. Pendekatan ini mendorong tumbuhnya proses edukasi secara mandiri dan masyarakat terlibat secara langsung sehingga menumbuhkan rasa tanggung jawab bersama atas untuk sama-sama berusaha mengatasi permasalahan yang ada. Pada kegiatan pengabdian ini, pendampingan masyarakat Desa Bango bersama tim pelaksana kegiatan melakukan revitalisasi sumber air bersih dalam hal ini sumur warga. Langkah awal dari kegiatan ini yaitu yaitu konstruksi tower penampungan air oleh Tim Pelaksana, dilanjutkan dengan pendampingan bersama masyarakat pembuatan tower penampungan air dengan menggunakan tiang penyangga berbahan dasar baja ringan dengan kapasitas $5500 \mathrm{~L}$ dan dilengkapi dengan sistem filtrasi menggunakan material yang tersedia di lingkungan sekitar yaitu pasir, kerikil dan ijuk. Dalam setiap tahapan operasional kegiatan dan pelaksanaan pendampingan, Tim Pelaksana mendampingi masyarakat Desa Bango dalam setiap kegiatan serta memberikan petunjuk teknis atau pengarahan sesuai dengan target yang diharapkan.

\section{Lokasi kegiatan}

Desa Bango, Kepulauan Mantehage,

Kecamatan Wori, Kabupaten Minahasa

Utara, Sulawesi Utara.

\section{Metode yang digunakan :}

Langkah-langkah operasional yang akan dilakukan oleh Tim Pengabdian di Kecamatan Bunaken Kepulauan untuk setiap tahun berjalan sesuai dengan paket alih teknologi yang akan dilakukan terdiri atas :
1. Penyamaan persepsi dan diseminasi
Teknologi
2. Pendampingan alih teknologi
3. Monitoring dan evaluasi kegiatan

\section{HASIL DAN PEMBAHASAN}

Program pertama yang dilakukan dalam kegiatan pengabdian ini yaitu konstruksi atau desain pembuatan tower penampungan air untuk mengalirkan air dari sumur ke tower sehingga warga tidak perlu menimba langsung dari sumur untuk mempermudah aktifitas masyarakat sedangkan hal yang menjadi permasalahan dalam pembuatan tower yaitu biaya langsiran dari kota Manado ke Pulau Mantehage yang sangat tinggi bila membuat tower berbahan dasar batu dan semen, permasalahan kedua yaitu tiang penyangga tower apabila terbuat dari besi akan mudah sekali mengalami oksidasi dan mengalami karat, kondisi tersebut akan membuat tiang penyangga cepat rusak dan tidak bisa menyangga tower air lagi.

Tower penampungan air dibuat dengan menggunakan tiang penyangga berbahan dasar baja ringan. Penggunaan baja ringan berdasarkan keunggulan baja ringan yang merupakan material dengan berat yang ringan, mudah dibentuk serta memiliki kekuatan yang tinggi (Martin et al, 2016). Tower penampungan air dengan kapasitas $5500 \mathrm{~L}$ menggunakan baja ringan lebih tahan terhadap kondisi lingkungan kepulauan yang kerap mengakibatkan material berunsur Fe mengalami oksidasi dan berkarat, dengan demikian tower yang dihasilkan dalam kegiatan ini lebih tahan karat sehingga tidak akan memerlukan peremajaan tulangan besi sesering tower-tower berbahan dasar besi pada umumnya. Hal ini berdasarkan pernyataan dari Moller (2006) yang menyatakan bahwa komposisi kimia dari baja akan membentuk lapisan oxy-hidroxide dalam lingkungan air laut, yang menghambat terjadinya korosi

Desain tower berbahan baja ringan dibangun berdasarkan hitungan dan simulasi menggunakan aplikasi autocad terhadap ketahanan baja ringan dari rangka tower yang dapat menampung air lebih dari $5500 \mathrm{~L}$ dan simulasi pergerakan air di dalam tower. Tahapan konstruksi atau desain ini sangat menentukan apakah struktur baja ringan tersebut dapat tahan menampung air sebanyak $5500 \mathrm{~L}$ dengan memperhatikan kondisi air yang dinamis apabila terjadi goncangan.

Hasil desain konstruksi tower penampungan air berbahan dasar baja ringan dapat dilihat pada Gambar 2 berikut: 

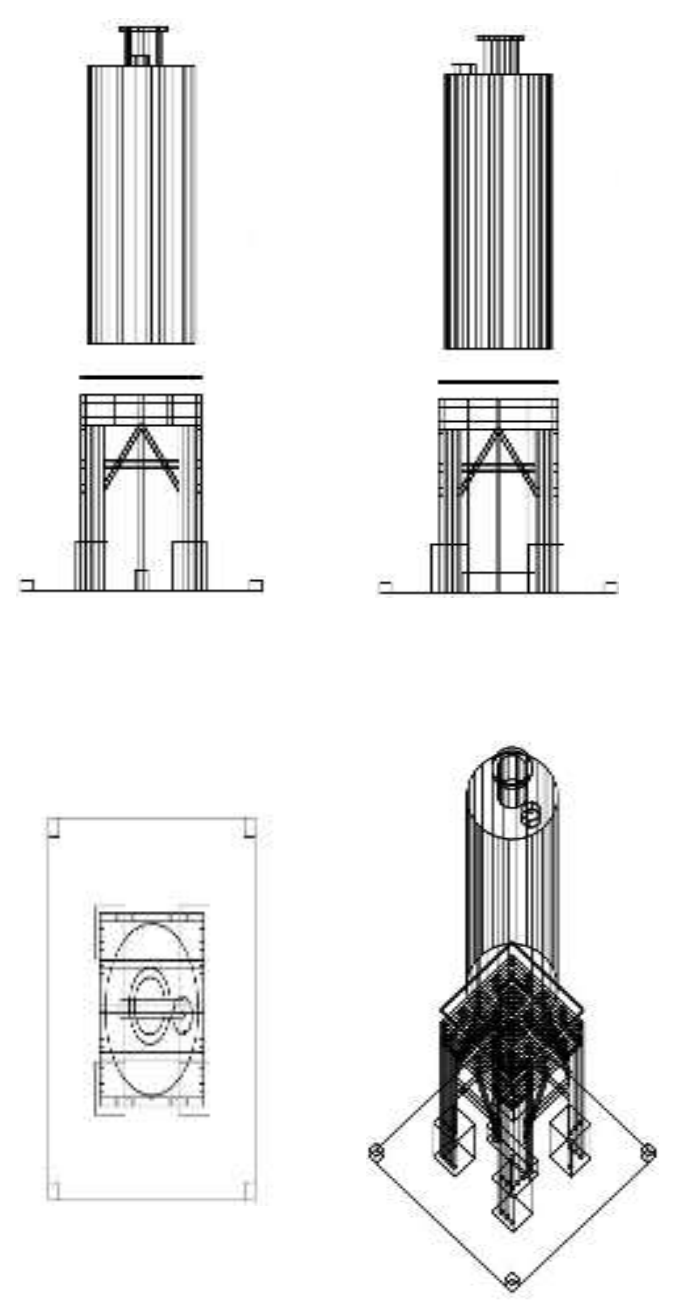

Gambar 2. Desain Konstruksi Tower

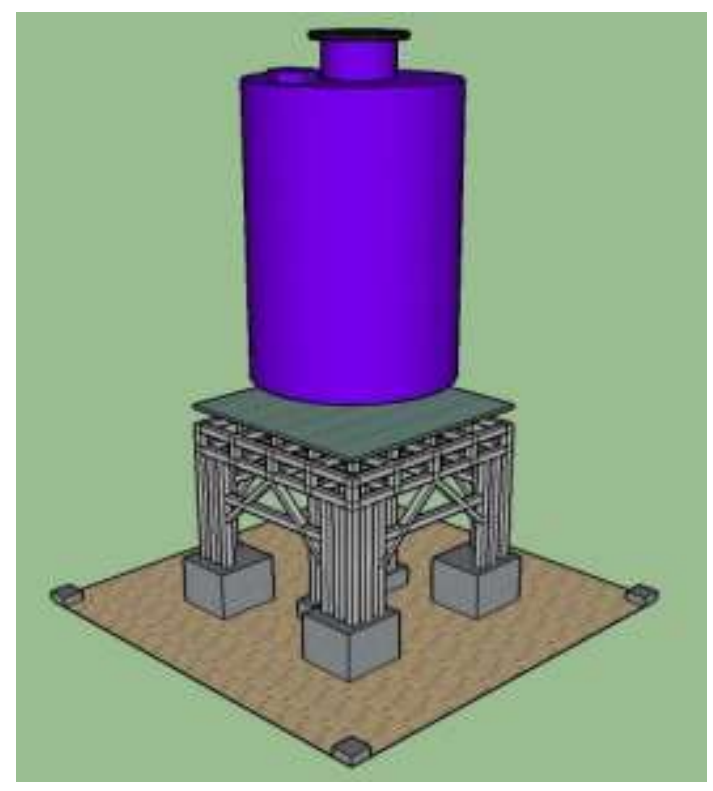

Tower yang dipersiapkan pada kegiatan ini merupakan konstruksi teknologi tepat guna khusus dirancang bagi masyarakat kepulauan yang memang berada dalam lingkungan salinitas tinggi sehingga tidak mudah mengalami proses oksidasi yang menyebabkan terjadi perkaratan. Tower ini juga dilengkapi dengan sistem filtrasi sederhana tiga tingkat (3 Stage) menggunakan bahan alami yaitu pasir, kerikil dan ijuk. Filtrasi yaitu Proses pemisahan solid-liquid dengan cara melewatkan liquid melalui media berpori atau bahan berpori untuk menyisihkan atau menghilangkan sebanyak-banyaknya butiran halus zat padat tersuspensi dari liquida dengan bantuan media filter seperti pasir misalnya: silika, antrasit, senyawa kimia atau mineral misalnya: kapur, zeolit, karbon aktif, resin, ion exchange, membran, biofilter atau teknik filtrasi lainnya (Widystuti dan Sari, 2011).

Sistem filtrasi ini membuat air yang berasal dari sumur warga menjadi lebih layak dan dapat dikonsumsi selain itu ketika musim hujan tiba masyarakat dapat menampung air hujan di tower dan dengan adanya sistem filtrasi membuat air hujan dapat dipergunakan langsung untuk kebutuhan air bersih warga. Sistem filtrasi dengan bahan sederhana seperti ini memudahkan bagi masyarakat Desa Bango untuk merevitalisasi filter dengan bahan-bahan dan material yang tersedia di lingkungan sekitar masyarakat. Sistem filtrasi dibuat menggunakan pipa paralon bertingkat (tiga stage), sedangkan bahan-bahan yang digunakan dalam sistem filtrasi bertingkat adalah pasir, bahan atau tingkat pertama yaitu pasir, dilanjutkan dengan kerikil dan tingkat terakhir adalah ijuk. Sistem filtrasi dapat dilihat pada Gambar 3 berikut 
Jurnal Pengabdian Multidisiplin

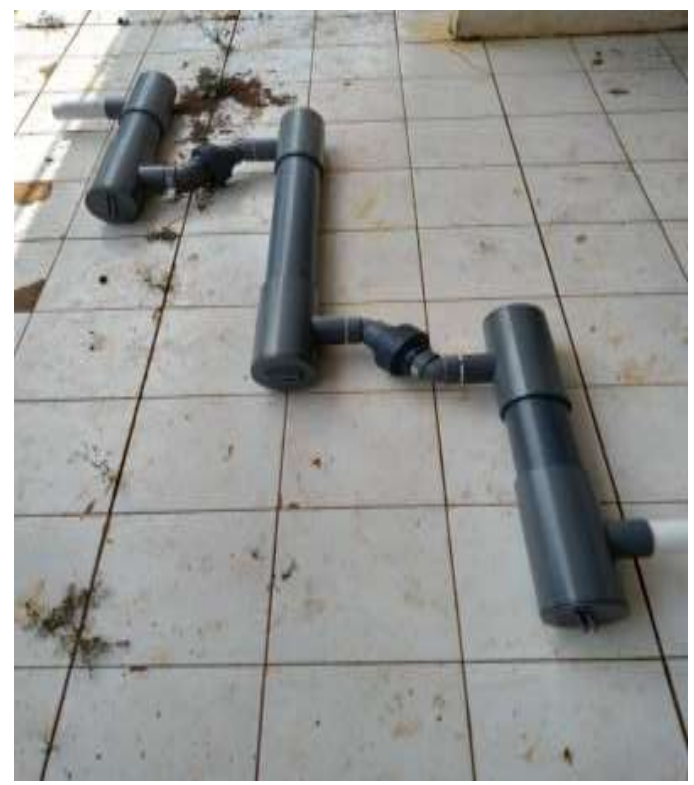

Gambar 3. Sistem Filtrasi 3 Stage

Hasil desain kontruksi Tim Pelaksana kemudian diimplementasikan dalam pendampingan pembuatan dan pendirian tower penampungan air bersama dengan masyarakat Desa Bango. Berikut ini merupakan beberapa dokumentasi kegiatan pendampingan bersama masyarakat Desa Bango.
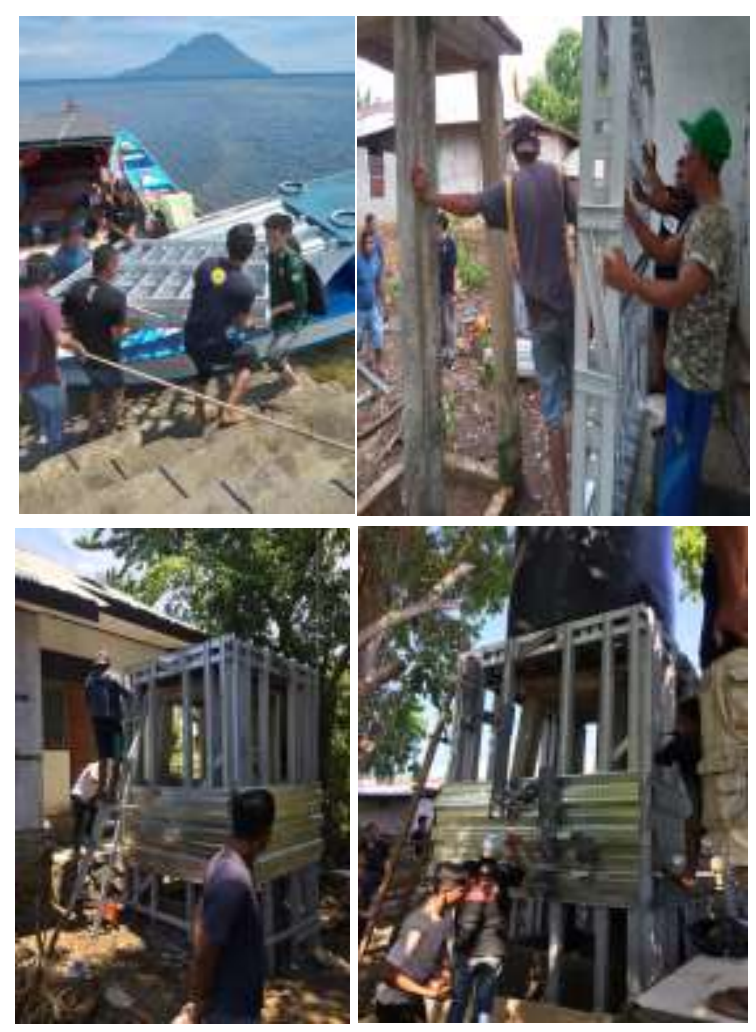

Gambar 4. Kegiatan Pendampingan Pembuatan dan Pendirian Tower Penampungan dan Sistem Filtrasi

Hasil dari kegiatan pendampingan ini adalah tower low cost-low maintenance penampungan air dan sistem filtrasi 3 stage yang dilengkapi dengan pompa diesel untuk mengalirkan air dari sumur warga ke tower penampungan air seperti terlihat pada Gambar 5 berikut

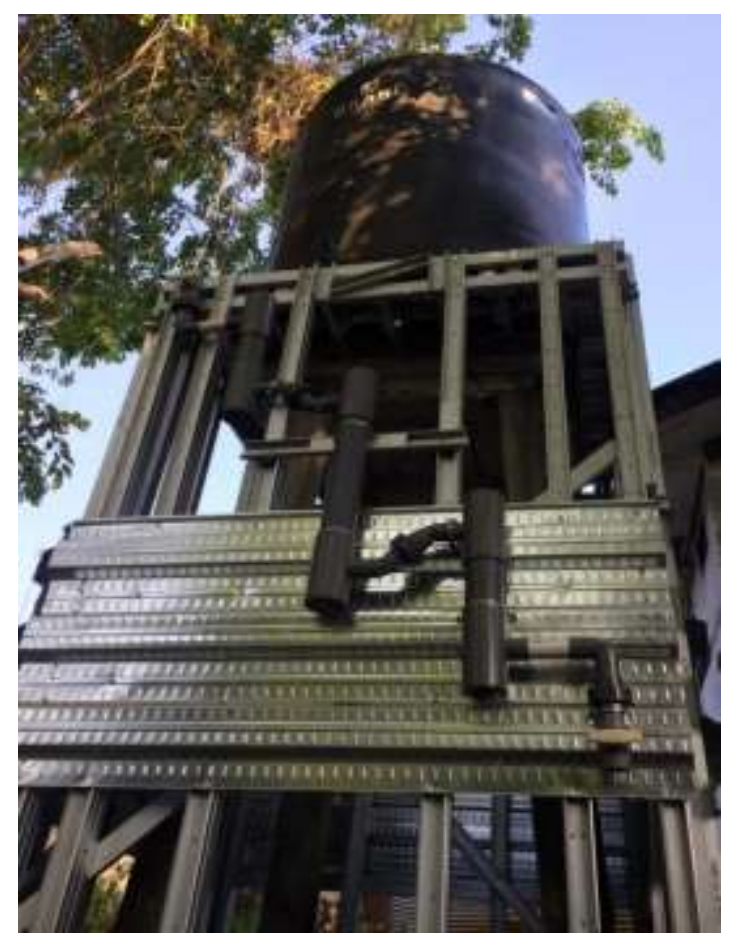

Gambar 5. Teknologi Filtrasi dan Tower Penampungan Low Cost - Low Maintenance

Sistem water catchment dengan memanfaatkan atap bangunan yang tidak terpakai di samping tower penampungan diberdayakan untuk memanfaatkan air hujan sebagai salah satu sumber air bagi masyarakat. Air hujan yang ditangkap oleh sistem tersebut akan di filter menggunakan sistem filtrasi yang dibangun dan dialirkan ke tower penampungan air sehingga sumber air bagi masyarakat bukan hanya berasal dari sumur saja tetapi juga berasal dari sumber air hujan sehingga kebutuhan 


\section{DAFTAR PUSTAKA}

Anonymous. 2012. Direktorat Pendayagunaan Pulau-pulau Kecil. Kementerian Kelautan dan Perikanan

Anonymous. 2017. Sulut Dalam Angka. Badan Pusat Statistik, Sulawesi Utara.

Möller, H., 2006, The Corrosion Behaviour of Steel in Sea Water, The Shoutern African Institute of Mining and Metallurgy 8th, International Corrosion Conference.

Martin, R., Susanti L., dan Perkasa, E.A. 2016. Rekayasa Sipil, vol 10 No.3.

Widystuti, S dan Sari A.S. 2011. Kinerja Pengolahan Air Bersih dengan Proses Filtrasi dalam Mereduksi Kesadahan. Jurnal Teknik Waktu, Vol. 9, No.1.

\section{KESIMPULAN DAN SARAN}

Program kegiatan PPDM bagi masyarakat Desa Bango Kepulauan Mantehage, Kecamatan Wori Kabupaten Minahasa Utara, Propinsi Sulawesi Utara adalah melakukan revitalisasi fasilitas umum sumber air bersih (sumur) warga dengan membuat tower penampungan air dengan kapasitas 5500 L merupakan konstruksi teknologi tepat guna dilengkapi dengan sistem filtrasi sederhana tiga tingkat (3 Stage) menggunakan bahan alami yaitu pasir, kerikil dan ijuk. Hasil evaluasi kegiatan bagi masyarakat adalah terciptanya revitalisasi sumber air bersih, terjadinya transfer teknologi serta dampak sosial bagi masyarakat yaitu perubahan pola kegiatan mandi dan mencuci yang sebelumnya dilakukan di sumur desa setelah pelaksanaan pengabdian kegiatan tersebut beralih ke rumah masingmasing.

\section{UCAPAN TERIMAKASIH}

Kegiatan ini dilaksanakan atas dasar pembiayaan dari Kementerian Riset, Teknologi dan DIKTI melalui Skim Program Pengembangan Desa Mitra (PPDM) dengan Nomor Kontrak 62/UN41.09/TU/2019. 